The Review of Higher Education

Spring 2001, Volume 24, No. 3, pp. 259-282

Copyright (c) 2001 Association for the Study of Higher Education

All Rights Reserved (ISSN 0162-5748)

Focus on Faculty: Challenges and Changing Roles

\title{
Dimensions of the Community College Faculty Labor Market
}

\section{Sandra Gahn and Susan B. Twombly}

The community college provides a significant labor market for faculty. This significance can be measured by numbers as well as by role. Public and private two-year colleges in the United States employ over 100,000 fulltime faculty members (Chronicle, 1998). Approximately one out of every three full-time faculty jobs in U.S. higher education is in a community/ two-year college (Huber, 1998). The import of this labor market extends well beyond mere numbers however. Community colleges are more likely to employ women and people of color as members of their faculties than most other types of colleges and universities (Finkelstein, Seal, \& Schuster, 1998; Huber, 1998). Moreover, community college faculty play a major role in educating new students. As Huber (1998) notes, they are educating 46 percent of all first-time freshmen, many of whom are students of color and/

Sandra Gahn is a Research Associate in the Student Affairs Office at the University of Missouri-Kansas City. Susan B. Twombly is Professor in the Department of Teaching and Leadership at the University of Kansas. An earlier version of this paper was presented at the annual meeting of the Association for the Study of Higher Education, November 1998, Miami, Florida. Address queries to Susan Twombly, 430 Joseph R. Pearson Hall, University of Kansas, 202 Bailey Hall, Lawrence, KS 66045; telephone: (785) 864-9721; fax: (785) 8645207; e-mail: Stwombly@ukans.edu. 
or are from low-income families. Many of these students require remedial or developmental education.

This labor market is facing major challenges. One is an aging faculty (Finkelstein, Seal, \& Schuster, 1998). The average age of community college faculty who responded to the NSOPF-93 Study was 55. Huber (1998) reported an average age of between 49 and 51 for faculty who responded to the Carnegie Foundation for the Advancement of Teaching Faculty Survey. These data suggest that large numbers of community college faculty may retire at virtually the same time and in the near future. Furthermore, they suggest that community colleges will need to hire large numbers of new faculty in a relatively short period of time. Faculties are concerned that one institutional response will be to replace full-time faculty with part-timers. On the other hand, past efforts to predict impending faculty shortages have proven less than accurate, leading both institutions and potential employees to wonder if all of the hoopla about faculty shortages is just that. Without information about the labor market, it is difficult for institutional policy makers and individuals seeking jobs to plan for the future.

Unfortunately, we have little information about the community college labor market. This study provides a base of essential information about this very important academic labor market. Two questions guide this study: (a) How likely are large numbers of community college faculty to retire in the near future? (b) Where have community colleges looked to find their new faculty?

The answers to these questions are critical, particularly for institutions that place such a high value on teaching and serve such an important role in educating new college students. Knowledge about the labor market can tell us much about community colleges themselves and what they value. For example, concurrent with the impending retirement of large numbers of faculty in community colleges, graduate schools are looking to the community college as a potential source of employment for the oversupply of Ph.D. graduates who are unable to find academic jobs in four-year colleges and universities. Under fire for enticing students to pursue graduate work and scholarly positions at four-year colleges and universities where the competition for jobs is very tight, graduate programs in the liberal arts and sciences are being encouraged to open the minds of their students to viable alternatives. One of the frequently mentioned alternatives is the community college. (See, for example, Michael Berubé \& Carry Nelson, 1994). Teaching in a community college is a natural though potentially less desirable alternative to university positions as a community college appointment allows prospective faculty members to use at least one aspect of their training-teaching at the college level. 
There is some indication that newly minted Ph.D.'s are in fact looking to community colleges for jobs. A recent article in the Chronicle of Higher Education reported that community colleges are receiving more applications from individuals with Ph.D.'s than ever before (Haworth, 1999). The response to this trend has been mixed. Some community colleges look on this surplus of Ph.D.'s as a way to "boost the credentials of its faculty" (Haworth, 1999, p. 1) and the reputation of the institution. Not surprisingly, others are more skeptical, arguing that the mission of the community college is teaching, not research, which is what Ph.D. candidates are trained to do. These skeptics fear that hiring new faculty members with Ph.D.'s will alter the mission of the two-year college (Haworth, 1999).

This assertion alone raises many questions about the community college faculty labor market. Have community colleges looked to the universities and new Ph.D. graduates to fill their faculty positions in the past? What are the future implications of this strategy for the mission of the community college if it commences or continues? It seems logical that hiring large numbers of Ph.D.'s straight out of graduate school may influence the traditional mission of the two-year college. If not Ph.D.'s, where will community colleges search to fill their needs? Will they hire faculty from other community colleges? From business and industry? The typical means of predicting future labor market behavior has been to examine past practice. However, unlike the academic labor market for four-year colleges and universities, the characteristics and dynamics of the community college faculty labor market are poorly understood at a macro level. A common assumption is that it functions like the labor market for four-year colleges and universities. To have some idea where faculty replacements in the community college might come from in the future, we need some understanding of the community college faculty labor market and how it has operated in the past.

To identify major characteristics of the labor market for community college faculty, we used the 1993 National Survey of Post-Secondary Faculty (NSOPF-93) to explore two broad questions:

1. How dynamic is the labor market? That is, how likely are community college faculty to be seeking other jobs or to retire? We also probe the relationship of these dynamic indicators to gender, length of time in current position, and academic area.

2. What are key characteristics of the community college faculty labor market? Is it best described as open (the most recent main job previous to the job respondents held at the time of the survey was not in the community college) or closed (previous job was in the community college)? Or does some other model best describe the market? Specifically, we looked first at the respondent's most recent main job (prior to the "current" job) and the employment sector it was in. We next examined whether the respondent's most recent main job differed from the current position by 
length of time held, by gender, and by academic area. Unfortunately, the NSOPF-93 data set does not allow us to explore regional boundaries of the labor market.

Although individual community colleges may have solved their labor needs, these questions, for the most part, remain unanswered at a macro level-hence, the tendency to assume that the community college labor market works like the four-year college and university market. It is partly this assumption that underlies the proposal that university-trained Ph.D.'s look for faculty jobs in community colleges. According to this logic, if graduate faculty mentors would only communicate to their graduate students the value of teaching in the community college and its legitimacy as a work place, community colleges would be waiting to snap up these Ph.D.'s. Yet previous research suggests that new Ph.D.'s suffer an expectation gap when they are actually hired to teach in community colleges (Cohen \& Brawer, 1989). Dr. Charles Carlson, president of Johnson County community College, recently commented that for a period of time his institution gave preference to $\mathrm{Ph}$.D. holders in hiring but soon abandoned that practice because of mismatched expectations on both sides (personal communication). So even if the competition for jobs at universities and four-year colleges might allow community colleges to hire Ph.D.'s, the community colleges themselves might not find Ph.D.'s the most desirable candidates in terms of their own institutional values (Haworth, 1999).

Answers to questions about the community college faculty labor market, as tentative as they might be, will not only shed light on the background characteristics and preparation deemed appropriate for community colleges, but they will also provide some insight into how community colleges act on their mission through hiring or how institutional status is derived. For example, community colleges who aspire to become some other kind of institution or whose status derives from research rather than teaching may value Ph.D.-prepared faculty. Organizational theorist W. Richard Scott (1992) makes a related argument that by knowing whether organizations are open to hiring from the outside or not, we learn something about how organizations manage their boundaries. Thus, identifying the structure of a labor market can tell us something about the boundaries of an organization or set of organizations.

\section{SuPPORTING LITERATURE}

\section{Labor Markets}

Labor markets are "arenas in which workers exchange their labor power ... for wages, status, and other job rewards" (Kalleberg \& Sorensen, 1979, p. 351). They are characterized by rules, institutions, and practices governing 
the process by which skills and training are exchanged for jobs and wages. Kalleberg and Sorensen (1979) add that labor markets are arenas "in which one or more of the following are similarly structured: employment, movement between jobs, development and differentiation of job skills, or wages" (p. 121). Jobs are components of organizations as well as of labor markets and, according to Scott (1992), if we want to know more about how individuals are matched with jobs "we need to know what positions exist, how they are connected, and what rules are employed for sorting workers among them" (p. 190). In the classical view of the labor market, "workers move freely from job to job and firm to firm, governed by pressures to maximize the fit between their skills and the requirements of their jobs, and hence their productivity and their earnings" (Scott, 1992, p. 188). In this view there are no barriers to the free movement of workers. This "free market" view of the labor market has been challenged by sociologists and institutional economists who argue that the labor market is segmented into many arenas. Within these arenas, information, opportunities, mobility, and rewards are differentially structured by occupational, industry, and organizational factors (Scott, 1992). Formal and informal rules govern mobility within individual segments of the labor market. For the purposes of this paper, we call these segments internal labor markets. Their "rules" determine which workers can compete in a market and which ones are preferred. Moving between and among segments is both determined and prevented by skill and training requirements, information about jobs, and other institutional "rules."

To the extent that labor markets serve as a way for organizations or sectors to manage social boundaries, internal labor markets are mechanisms for securing and keeping employees within their boundaries. However, several factors have led some labor market sectors to engage in external or boundary-spanning labor practices such as hiring part-time employees or making short-term administrative appointments.

\section{The Academic Labor Market}

Beliefs about the academic labor market in the United States have long been structured by the status or prestige system-in short, by institutional type-that Caplow and McGee (1958) first described. Prestige has typically been linked to universities' research function, rather than teaching. Scholarly and local beliefs continue to perpetuate this idea of a market structured by prestige or status, with moderate movement between sectors. A person can easily move from the "major" to the "minor" leagues, but a move in the reverse direction requires some sort of exchange, such as a better job at a lower-prestige institution or a lower-status job at a higher prestige institution. Burke (1988) concluded that, despite a major shift from a seller's to a buyer's academic market, between 1958 and 1988, prestige still dominated the labor market of research universities. 
In Caplow and McGee's scheme, community colleges were the "bush" league. Of course, community colleges had yet to experience their dramatic growth or to assume the central function they have today. But even though this sector of higher education has exploded in the intervening $40+$ years, such studies of the academic marketplace as Burke's 1988 replication of the Caplow and McGee study do not deal with community college faculty. Likewise, Schuster (1995), Fairweather (1996), Finnegan (1993) and Youn and Gamson (1994) all focus on four-year college and university faculty. Finkelstein, Seal, and Schuster (1998) do include community college faculty in their analysis of transitions among faculty but still give less attention to this group than to faculty in four-year colleges and universities.

Surprisingly, not even community college scholars have written much about the community college faculty labor market. When community college faculty are the focus of attention, the result is typically a descriptive profile (e.g., Carter \& Ottinger, 1992; Huber, 1998; Phillippe, 1995). Others have studied faculty attitudes (Huber, 1998), dissatisfaction (Colgrove \& Shinville, 1993) and job satisfaction (Happ \& Yoder, 1991; Filan, Okun, \& Witter, 1986). Recently, Fugate (1997), Bayer and Braxton (1998) and Palmer (1994) have explored different aspects of community college professionalization. Fugate looked for identifiable career stages in faculty careers but concluded there were really only two: the first two years and post-tenure. Bayer and Braxton examined normative aspects of community college faculty careers and concluded that they are more professionalized than previously recognized in terms of faculty's understanding of acceptable normative behaviors. They conclude that community college faculty are thus as ready as their four-year counterparts to accept self-regulation. Palmer (1994) has tracked scholarly activities of community college faculty. Still, none of these author deal with the nature of the labor market per se.

Existing community college labor market studies occurred in the late 1960s as rapidly growing community colleges struggled to fill administrative and faculty positions. Many of these studies confirmed the trend toward hiring administrators from within the two-year college world rather than from outside (e.g., Schultz, 1965; Wing, 1971). More recently, Twombly (1988) confirmed the trend toward an internal market for community college administrators; $61 \%$ of presidents and $79 \%$ of chief academic officers had held previous positions at a two-year college. However, the existence of clearly defined career ladders was more evident for some top-level administrative positions than for others.

\section{Community College Characteristics Affecting the Labor Market}

As Burke (1988) points out, external factors affect the structure and functioning of the academic labor market. In addition to whether the market is or was a seller's market (i.e., many jobs for the available pool of qualified 
applicants) or a buyer's market (i.e., many more qualified job seekers than jobs available), other factors affect the nature of a labor market. In particular, the nature and mission of the community college differentiate it from four-year colleges and universities in ways that potentially affect the labor market.

Kevin Dougherty (1994) calls the community college "the contradictory college." As he points out in his important book, the community college faces a controversy over its mission. Should it continue to be a comprehensive institution offering the transfer function, occupational training, adult education, short-term training for business and industry and remedial education, or should it narrow its role? For this discussion, the important point is that the community college has multiple roles and missions that may condition the structure of the labor market. On the one hand, the community college offers the first two years of higher education equal in quality and breadth to that found in a four-year institution. On the other hand, it provides occupational training in various fields from refrigeration technology to nursing. Additionally, community colleges are frequently called upon to offer adult education for the community, short-term training for local business and industry, and remedial education for those who need it. Furthermore, community colleges are known as teaching institutions where research is deemphasized (Grubb et al., 1999; Huber, 1998). Diversity of programs offered and the fact that the associate degree is the highest degree offered undoubtedly affect the nature of the community college faculty labor market, the kinds of people sought by this sector, and also those who seek jobs in them.

It is likewise possible that the community college's historical location either as an upward extension of the local public school system or jettisoned lower division of four-year institutions continues to affect the labor market. This was certainly true in the 1970s as newly founded or growing colleges drew from public schools as they scrambled to fill faculty and administrative posts. However, some research suggests that, with the maturing of even the most recently founded community colleges, these ties have weakened (Tillery \& Deegan, 1985; Twombly 1988).

In addition, community colleges are by definition "community"-focused institutions. What role does that focus play in structuring the labor market? although this study cannot answer the specific question of what role this local focus plays in faculty hiring, several authors have alluded to its importance (Brewer \& Gray, 1992; Dougherty, 1989). One specific influence is that if, in fact, good teaching is the main criteria for selecting faculty-a fact which Grubb et al. (1999) dispute-then it is probably not necessary for community college to seek talent nationally. Indeed, it is much cheaper to search locally. Thus, although there may be well-functioning markets for four-year college and university faculty and for disciplines within those 
markets, at this point we cannot draw the same conclusion about community college faculty.

Given the lack of information on the labor market for faculty, we approached our analysis inductively. Rather than test hypotheses, our goal was to describe various aspects of the community college academic labor market. Is it best characterized as a closed or internal labor market in the sense that faculty are hired from other two-year colleges? Or is does it approximate an external or open market in the sense that faculty are hired from other enterprises external to the community college? The availability of the large NSOPF-93 data set allows us to answer some of these questions and to generate questions to be answered through other types of studies.

\section{Research Procedures}

To answer our questions, we used data from the 1993 National Survey of Post-secondary Faculty (NSOPF-93) conducted by the National Center for Education Statistics (NCES). The data set contains information on 8,187 respondents who claimed some role in community/two-year colleges in the fall of 1992. To conduct this exploratory study with a manageable data set, we narrowed the sample by selecting:

- only public two-year colleges

- only full-time faculty, eliminating part-time

- only colleges with enrollments of 1,000 or more

- faculty who described their principal activity as teaching (Question 2 on the survey)

- faculty with "regular" appointments, eliminating those who answered Question 11 by checking "acting," "affiliate or adjunct," "visiting," "assigned by religious order," "clinical," or "research"

These criteria resulted in a sample of 3,104 full-time faculty. Because the community college sector underwent tremendous growth in the 1960s and 1970 s, the labor market is likely to have changed over time. Additionally, respondents have been in their current jobs for very different lengths of time. Thus, it is important to examine previous jobs by the length of time individuals had held the current position. To take length of time in current position into consideration, we grouped faculty into four cohorts by how long they had held their current job as of 1992: 0-3 years $(n=857), 4-10$ years $(n=741), 11-19$ years $(n=773)$, and 20-37 years $(n=733)$. We chose these groupings because two-year colleges typically award tenure after two or three years. Thus, faculty in their current jobs three or fewer years may properly be regarded as "new" faculty. Furthermore, this was the only marker Fugate (1997) could identify in stages of faculty careers in two-year colleges. In addition, this division yielded four groups of approximately equal 
size. Keeping in mind that respondents completed the survey in 1992, faculty in their current job 0-3 years obtained those jobs between 1989 and 1992; the 4-10 year group includes individuals who obtained their current jobs between 1982 and 1988, the 11-19 year group between 1973 and 1981; and the 20+ year group between 1955 and 1972. We suggest that, used cautiously, analysis of data by these groups can serve as a proxy for changes over time.

We answered our first question by using the responses to queries in the survey about leaving the current job for another job and about retirement. Answers to our second research question came from analyzing responses to item 19 of the NSOPF-93 survey, which item asks about jobs ending before the beginning of the 1992 fall term. Such employment would be the main job held prior to the job held by the respondent when she or he filled out the survey. The response set includes nine choices: two-year institution, fouryear institution, elementary/secondary schools, for-profit business, etc. This question also asks about the respondent's main responsibility in the previous job (i.e., teaching, research, other).

Given our interest in a descriptive, inductive analysis, we did not weight the data as we would have done if performing statistical tests. We realize that this procedure could pose some problems in generalizing from the data.

This study has three primary limitations. The first is the age of the survey data. There have been major changes in the environment for community colleges since 1992. Second, the questions we could ask of the data were limited by the questions asked on the survey. For example, we do not know how individuals actually get jobs in community colleges (where the jobs are advertised, whether there are searches as in four-year universities, etc.). It is also difficult to determine the sequence of when the highest degree was earned and when jobs were obtained. Nor, unfortunately, will the data permit an answer to Dougherty's intriguing suggestion about the local nature of faculty labor market. Nonetheless, the size of the data set allows us to perform preliminary analyses that can be further tested when a new version of the data is available and by local in-depth studies.

A third limitation is our use of cross-sectional data to draw conclusions about past behavior. We can really comment only on differences among individuals who have been in their current positions varying amounts of time. There may have been significant cohort factors affecting hiring patterns in earlier years that would become obvious if we had equivalent data from sufficient years back. We did not feel that the length of time between NSOPF 1988 and 1993 studies was long enough to yield better longitudinal data. 


\section{FINDINGS}

\section{Retirement and Mobility in the Community College Labor Market}

We analyzed the responses to several questions that provide some insight into how dynamic the community college labor market is and will be in the future. For these analyses we used the entire sample of 3,104 faculty who met the criteria specified in the method section. The first indicator of market dynamism is the percentage of faculty in their current jobs three or fewer years. More than a quarter $(27.6 \%, \mathrm{n}=857)$ were relatively new to their jobs. This figure suggests a fairly high rate of mobility. This group was also the most likely to be looking for another job in the near future. Huber (1998) reports that community college are second only to research university faculty in stability, with community college faculty keeping the same job an average of 14.5 years.

Age. As expected, we found a positive relationship between age and length of time in the current position. Those in the job 20 years or more $(n=733)$ had a mean age of 55.1 compared to mean ages of 49.9 for those in the job 11-19 years $(\mathrm{n}=773), 46.2$ for those in the job $4-10$ years $(\mathrm{n}=741)$ and 43.6 for those in the job three years or less $(n=857)$. Male faculty members, with a mean age of 49.8 , were slightly older than their female counterparts (47.2). Those in their current job the longest had also stayed at their previous job the longest ( 9.9 years compared to 4.9 for those in the current job 3 or fewer years). Perhaps younger faculty are really more mobile than older faculty, despite the common perception that young professionals are less mobile because of dual career families and tight job markets.

Plans. About $20 \%$ or 146 of those faculty on the job 20 years or more indicated that they were "somewhat likely" to retire within three years while another $24 \%(\mathrm{n}=177)$ were "very likely" to do so. Thus, approximately $44 \%$ of faculty in their jobs 20 years or more were at least somewhat likely to retire in 1995-1996. As expected, $92 \%$ of faculty in their current jobs three or fewer years, $88 \%$ of those in their current jobs $4-10$ years, and $81 \%$ of those in their current jobs 11-19 years reported they were "not likely at all" to retire within the next three years.

The mean reported age of likely retirement from all employment was 65.1 years for men and 63.9 for women. The mean anticipated retirement age for the entire sample was 64.5. Interestingly, the mean age at which respondents said they are likely to retire from a post-secondary institution was 61.5, three years younger than anticipated retirement age from all employment. What individuals anticipate doing in the three intervening years is not clear. It is also not clear why women anticipate retiring earlier than men. Possibly women are less satisfied with their community college work (Townsend, 1998). Another plausible-albeit sexist-explanation is that 
men are the main source of income in a family and have to work longer. Conversely, perhaps women have the luxury of providing the "second" income in a family and thus their income is more expendable. It is also possible that women retire early to join husbands who are already enjoying retirement. Only slightly more than half of the entire sample said they were likely to take early retirement. Of these, men (55\%) were more likely than women $(51 \%)$ to report the possibility.

Community college faculty did not seem anxious to leave their current job for one outside post-secondary education. Overall 88\% said they were "not at all likely" to look for such a position but were more likely to say they would seek a full-time job at another post-secondary institution. Forty percent $(\mathrm{n}=$ $338)$ of those in the $0-3$ group, $35.8 \%(n=255)$ in the $4-10$ group and $22 \%$ $(\mathrm{n}=175)$ of those in the 11-19 year group, and $15 \%(\mathrm{n}=106)$ of those in the $20+$ group were "somewhat" or "very" likely to seek such a job. As expected, those who had been in their current job the shortest length of time were more likely to express a desire to move. Of course, they were only expressing intent, and it may well have been wishful thinking on their part. According to our study, approximately $30 \%$ have moved to another two-year college, and the percentage moving to four-year colleges is probably much smaller.

From these data, the community college faculty labor market has both dynamic aspects and stable aspects. The retirement group may be smaller than anticipated while those newest to their current job may intend to move more than anticipated.

\section{Dimensions of the Labor Market}

To understand the labor market for community college faculty, we examined the jobs held by community college faculty immediately before assuming their current post (the previous main job). Of our total 3,104 sample, $65 \%$, or 2,011 , reported a previous main job. A rather large number $(1,093)$ reported no previous main job. Possibly many had been hired in their current position as their first and only job many years earlier. Certainly it is possible that some of our sample was hired directly from graduate school or some educational experience. It is also possible that respondents did not answer this portion of the survey.

Previous main jobs of the 2,011 respondents who reported them appear in Table 1. Although other two-year colleges were the main source of current two-year college faculty, only a third of the respondents reported holding a job at a two-year college immediately before assuming their current position. Collectively, positions in four-year colleges/universities $(n=326$, $16.2 \%)$, elementary and secondary schools $(\mathrm{n}=316,15.7 \%)$, and for-profit business ( $n=242,12.0 \%)$ accounted for $44 \%$ of the previous jobs. Thus, a sizable proportion—a majority, in fact—of recent hires came from outside two-year colleges. 


\section{TABLE 1}

\section{Employment Sector of Most Recent Main Job by Length of Time in Current Position}

\begin{tabular}{|c|c|c|c|c|c|}
\hline \multirow[t]{2}{*}{ Sectors } & $0-3$ Yrs & 4-10 Yrs & \multirow[t]{2}{*}{ 11-19Yrs } & \multirow[t]{2}{*}{$20+Y r s$} & \multirow[t]{2}{*}{ Totals } \\
\hline & \multicolumn{2}{|c|}{ Number/Percentage } & & & \\
\hline Four-Year College & $\begin{array}{r}138 \\
18.4\end{array}$ & $\begin{array}{r}106 \\
16.9\end{array}$ & $\begin{array}{r}47 \\
11.5\end{array}$ & $\begin{array}{r}35 \\
15.4\end{array}$ & $\begin{array}{r}326 \\
16.2\end{array}$ \\
\hline Two-Year College & $\begin{array}{r}248 \\
33.2\end{array}$ & $\begin{array}{r}184 \\
29.4\end{array}$ & $\begin{array}{r}132 \\
32.2\end{array}$ & $\begin{array}{r}92 \\
40.5\end{array}$ & $\begin{array}{r}656 \\
32.6\end{array}$ \\
\hline $\begin{array}{l}\text { Elementary/Secondary } \\
\text { Schools }\end{array}$ & $\begin{array}{r}104 \\
13.9\end{array}$ & $\begin{array}{r}95 \\
15.2\end{array}$ & $\begin{array}{r}74 \\
18.0\end{array}$ & $\begin{array}{r}433 \\
18.9\end{array}$ & $\begin{array}{r}16 \\
15.7\end{array}$ \\
\hline Consulting & $\begin{array}{r}32 \\
4.3\end{array}$ & $\begin{array}{r}36 \\
5.8\end{array}$ & $\begin{array}{r}25 \\
6.1\end{array}$ & $\begin{array}{r}8 \\
3.5\end{array}$ & $\begin{array}{r}101 \\
5.0\end{array}$ \\
\hline Hospital/Health & $\begin{array}{r}76 \\
10.2\end{array}$ & $\begin{array}{r}55 \\
8.8\end{array}$ & $\begin{array}{r}39 \\
9.5\end{array}$ & $\begin{array}{r}81 \\
3.5\end{array}$ & $\begin{array}{r}78 \\
8.9\end{array}$ \\
\hline Nonprofit & $\begin{array}{r}17 \\
2.3\end{array}$ & $\begin{array}{r}8 \\
1.3\end{array}$ & $\begin{array}{r}8 \\
2.0\end{array}$ & $\begin{array}{r}6 \\
2.6\end{array}$ & $\begin{array}{r}39 \\
1.9\end{array}$ \\
\hline Business & $\begin{array}{r}77 \\
10.3\end{array}$ & $\begin{array}{r}92 \\
14.7\end{array}$ & $\begin{array}{r}49 \\
12.0\end{array}$ & $\begin{array}{r}24 \\
10.6\end{array}$ & $\begin{array}{r}242 \\
12.0\end{array}$ \\
\hline Federal Government & $\begin{array}{r}37 \\
4.9\end{array}$ & $\begin{array}{r}31 \\
5.0\end{array}$ & $\begin{array}{r}22 \\
5.4\end{array}$ & $\begin{array}{r}7 \\
3.1\end{array}$ & $\begin{array}{r}97 \\
4.8\end{array}$ \\
\hline Other & $\begin{array}{r}19 \\
2.5\end{array}$ & $\begin{array}{r}19 \\
3.0\end{array}$ & $\begin{array}{r}14 \\
3.4\end{array}$ & $\begin{array}{r}4 \\
1.8\end{array}$ & $\begin{array}{r}56 \\
2.8\end{array}$ \\
\hline Totals & $\begin{array}{l}748 \\
100\end{array}$ & $\begin{array}{l}626 \\
100\end{array}$ & $\begin{array}{l}410 \\
100\end{array}$ & $\begin{array}{l}227 \\
100\end{array}$ & 2,011 \\
\hline
\end{tabular}

Nearly $60 \%$ of the respondents had taught as their primary responsibility in the previous job. Ten percent had held technical jobs as programmers, chemists, engineers, etc. Another $9.1 \%$ had held administrative jobs. The vast majority $(80.6 \%)$ had worked full-time at their previous job. It appears that teaching or working in a related field is a desirable credential-even a requirement-for a community college faculty job.

When we looked at previous main job by length of time in current position, we found some expected differences. Of the respondents who reported a previous main job, 748 (37\%) had been in their current job $0-3$ years; 626 (31\%), 4 -10 years; 410 (20.3\%), 11-19 years, and 227 (11.3\%), 20+ years. Table 1 reports the employment sector of the previous main job by group. 
The data displayed in Table 1 indicate some subtle differences by group for this particular set of community college faculty. Two-year colleges served as the source of $40 \%$ of faculty in the $20+$ group, gradually declining to $29.4 \%$ among the 4-10 year group. One-third of the 0-3 year group held their previous job in other two-year colleges. However, the newest community college faculty (0-3 years) were somewhat more likely to have been hired from a job in the four-year college/university sector than those in the other groups. This finding is somewhat unexpected, given the common perception that, as community colleges have matured, they seek candidates primarily from within the community college ranks. On the other hand, the percentage of community college faculty hired from jobs in the elementary/secondary sector is lowest among the 0-3 year group.

Other changes among the groups probably reflect program growth and contraction. For example, the percentage of faculty who previously worked in health care increased from 3.5 in the $20+$ group to 10.2 in the $0-3$ year group. For-profit business as a previous main job is something a puzzle without a conclusive pattern that can be determined from these data.

In sum, as community colleges have matured, they have separated themselves somewhat from elementary and secondary schools and identified more with four-year colleges and universities.

Educational requirements or highest earned degree. Our analysis found that the master's degree was indeed the "terminal" degree for community college faculty. Fully two-thirds $(\mathrm{n}=2,041)$ of our respondents reported that the master's degree was their highest. Seventeen percent $(N=525)$ reported holding a doctorate and $10 \%(\mathrm{~N}=317)$ a bachelor's degree. Given the structure of the survey from which the NSOPF-93 data are drawn, we could not determine if respondents were hired straight out of graduate programs; but 170 (approximately 15\%) of the 1,077 respondents who reported no previous position apparently earned their highest degree the same year they started their current position. Twenty-seven percent earned their degree while holding their current job, and the majority (58\%) earned their highest degree before being hired for their current position.

When we analyzed the highest degree by length of time in current position, we see just how stable the "requirements" to participate in the community college faculty labor market are. (See Table 2.) Some interesting and perhaps unexpected patterns emerged. For example, the group in their jobs the fewest number of years are not much more likely to hold a doctoral degree than those hired into their current positions some time ago. The group with the highest percentage of doctoral degrees is the 20+ group. This group has had more time to earn the doctoral degree on the job, or it may be that doctorate-holders took advantage of the growth spurt of twoyear colleges between 1955 and 1972. Likewise they may have taken advantage of Kellogg Foundation programs to help community college personnel 


\section{TABLE 2}

\section{Highest Degree Earned by Degree and Length of Time in Current Position}

\begin{tabular}{|c|c|c|c|c|c|}
\hline \multirow[t]{2}{*}{ Sectors } & $0-3$ Yrs & 4-10 Yrs & \multirow[t]{2}{*}{ 11-19Yrs } & \multirow[t]{2}{*}{$20+Y r s$} & \multirow[t]{2}{*}{ Totals } \\
\hline & \multicolumn{2}{|c|}{ Number/Percentage } & & & \\
\hline Professional & $\begin{array}{r}14 \\
1.7\end{array}$ & $\begin{array}{r}21 \\
2.9\end{array}$ & $\begin{array}{r}20 \\
26.1\end{array}$ & $\begin{array}{r}9 \\
1.2\end{array}$ & $\begin{array}{r}64 \\
2.0\end{array}$ \\
\hline Doctoral & $\begin{array}{r}141 \\
16.6\end{array}$ & $\begin{array}{r}111 \\
15.2\end{array}$ & $\begin{array}{r}117 \\
15.3\end{array}$ & $\begin{array}{r}156 \\
21.4\end{array}$ & $\begin{array}{r}525 \\
17.1\end{array}$ \\
\hline Master's & $\begin{array}{r}531 \\
62.7\end{array}$ & $\begin{array}{r}476 \\
65.1\end{array}$ & $\begin{array}{r}521 \\
68.0\end{array}$ & $\begin{array}{r}514 \\
70.6\end{array}$ & $\begin{array}{r}2,041 \\
66.4\end{array}$ \\
\hline Bachelor's & $\begin{array}{r}119 \\
14.0\end{array}$ & $\begin{array}{r}87 \\
11.9\end{array}$ & $\begin{array}{r}76 \\
9.9\end{array}$ & $\begin{array}{r}35 \\
4.8\end{array}$ & $\begin{array}{r}317 \\
10.3\end{array}$ \\
\hline Two+ Plus Years College & \}e $\begin{array}{r}1 \\
0.1\end{array}$ & $\begin{array}{r}9 \\
1.2\end{array}$ & $\begin{array}{r}6 \\
1.0\end{array}$ & $\begin{array}{r}1 \\
0.1\end{array}$ & $\begin{array}{r}17 \\
0.6\end{array}$ \\
\hline Associate & $\begin{array}{r}31 \\
3.7\end{array}$ & $\begin{array}{r}21 \\
2.9\end{array}$ & $\begin{array}{r}17 \\
2.2\end{array}$ & $\begin{array}{r}11 \\
1.5\end{array}$ & $\begin{array}{r}80 \\
2.6\end{array}$ \\
\hline Some College & $\begin{array}{r}10 \\
1.2\end{array}$ & $\begin{array}{r}7 \\
1.0\end{array}$ & $\begin{array}{r}9 \\
1.2\end{array}$ & $\begin{array}{r}2 \\
0.3\end{array}$ & $\begin{array}{r}28 \\
1.0\end{array}$ \\
\hline Totals & $\begin{array}{l}847 \\
100\end{array}$ & $\begin{array}{l}731 \\
100\end{array}$ & $\begin{array}{l}766 \\
100\end{array}$ & $\begin{array}{l}728 \\
100\end{array}$ & 3,072 \\
\hline
\end{tabular}

earn doctoral degrees. Another interesting finding is that faculty in their jobs $0-3$ years are about three times as likely (14\%) than any other group to hold bachelors' degree as their highest degree than the 20+ year group $(4.8 \%)$. Given the maturing of the community college labor market, this finding is somewhat surprising and may reflect the increasing number of faculty hired into professional/technical programs or developmental education programs. It may also reflect the fact that community college faculty may earn higher degrees while employed in the community college.

Previous main job by academic area. Some interesting patterns emerged when we analyzed earlier previous main job by academic area. (See Table 3.) Over a quarter of humanities and social science faculty had previously worked in the four-year college/university sector. Although these proportions are lower than the percentage of faculty in these areas holding previous jobs in two-year colleges, they nonetheless are a substantial fraction. Science faculty, in contrast, were much more likely to have previously worked in other two-year colleges (57.1\%) rather than elementary or secondary schools $(20.0 \%)$ or other four-year colleges $(17.8 \%)$. Not surprisingly, oc- 
TABLE 3

\section{Employment Sector of Most Recent Job by Selected ACADEMIC AREAS}

\begin{tabular}{|c|c|c|c|c|c|c|}
\hline & $\begin{array}{l}\text { Occupa- } \\
\text { tional }^{1}\end{array}$ & Business & Health & \multirow[t]{2}{*}{ Humanities } & \multirow[t]{2}{*}{$\begin{array}{c}\text { Social } \\
\text { Sciences }\end{array}$} & \multirow[t]{2}{*}{ Sciences } \\
\hline \multicolumn{4}{|c|}{ Number/Percentage } & & & \\
\hline Four-Year College & $\begin{array}{r}16 \\
7.2\end{array}$ & $\begin{array}{r}21 \\
10.4\end{array}$ & $\begin{array}{r}30 \\
11.1\end{array}$ & $\begin{array}{r}87 \\
26.6\end{array}$ & $\begin{array}{r}58 \\
26.7\end{array}$ & $\begin{array}{r}56 \\
17.8\end{array}$ \\
\hline $\begin{array}{l}\text { Two-Year College } \\
\text { Elementary/Secondar }\end{array}$ & $\begin{array}{r}63 \\
28.5\end{array}$ & $\begin{array}{r}69 \\
34.2\end{array}$ & $\begin{array}{r}64 \\
23.7\end{array}$ & $\begin{array}{r}121 \\
37.0\end{array}$ & $\begin{array}{r}69 \\
31.8\end{array}$ & $\begin{array}{r}124 \\
57.1\end{array}$ \\
\hline Schools & $\begin{array}{r}27 \\
12.2\end{array}$ & $\begin{array}{r}31 \\
15.3\end{array}$ & $\begin{array}{r}12 \\
4.4\end{array}$ & $\begin{array}{r}70 \\
21.4\end{array}$ & $\begin{array}{r}30 \\
13.8\end{array}$ & $\begin{array}{r}63 \\
20.0\end{array}$ \\
\hline Consulting & $\begin{array}{r}19 \\
8.6\end{array}$ & $\begin{array}{r}12 \\
5.9\end{array}$ & $\begin{array}{r}6 \\
2.2\end{array}$ & $\begin{array}{r}5 \\
1.5\end{array}$ & $\begin{array}{r}9 \\
4.1\end{array}$ & $\begin{array}{r}16 \\
5.1\end{array}$ \\
\hline Hospital/Health & $\begin{array}{r}4 \\
1.8\end{array}$ & $\begin{array}{r}3 \\
1.5\end{array}$ & $\begin{array}{r}138 \\
51.1\end{array}$ & $\begin{array}{r}5 \\
1.5\end{array}$ & $\begin{array}{r}8 \\
3.7\end{array}$ & $\begin{array}{r}11 \\
3.5\end{array}$ \\
\hline Nonprofit & $\begin{array}{r}3 \\
1.3\end{array}$ & $\begin{array}{r}1 \\
1.2\end{array}$ & $\begin{array}{r}0 \\
0.0\end{array}$ & $\begin{array}{r}8 \\
2.4\end{array}$ & $\begin{array}{r}8 \\
3.7\end{array}$ & $\begin{array}{r}3 \\
1.0\end{array}$ \\
\hline Business & $\begin{array}{r}58 \\
26.2\end{array}$ & $\begin{array}{r}51 \\
25.2\end{array}$ & $\begin{array}{r}5 \\
1.8\end{array}$ & $\begin{array}{r}18 \\
5.5\end{array}$ & $\begin{array}{r}11 \\
5.1\end{array}$ & $\begin{array}{r}23 \\
7.3\end{array}$ \\
\hline Federal Government & $\begin{array}{r}18 \\
8.1\end{array}$ & $\begin{array}{r}11 \\
5.4\end{array}$ & $\begin{array}{r}9 \\
3.3\end{array}$ & $\begin{array}{r}8 \\
2.4\end{array}$ & $\begin{array}{r}19 \\
8.8\end{array}$ & $\begin{array}{r}13 \\
4.1\end{array}$ \\
\hline Other & $\begin{array}{r}13 \\
5.9\end{array}$ & $\begin{array}{r}3 \\
1.5\end{array}$ & $\begin{array}{r}6 \\
2.2\end{array}$ & $\begin{array}{r}5 \\
1.5\end{array}$ & $\begin{array}{r}5 \\
2.3\end{array}$ & $\begin{array}{r}6 \\
1.9\end{array}$ \\
\hline Totals & $\begin{array}{l}221 \\
100\end{array}$ & $\begin{array}{l}202 \\
100\end{array}$ & $\begin{array}{l}270 \\
100\end{array}$ & $\begin{array}{l}327 \\
100\end{array}$ & $\begin{array}{l}217 \\
100\end{array}$ & $\begin{array}{l}315 \\
100\end{array}$ \\
\hline $\begin{array}{l}\text { 'This category includes } \\
\text { engineering, art, comm } \\
\text { could be placed in the sc } \\
\text { and those codes listed u } \\
\text { categories. Another } 59 \text { i } \\
\text { applicable." }\end{array}$ & $\begin{array}{l}\text { ly those fie } \\
\text { cations, ed } \\
\text { lces or occ } \\
\text { er vocation } \\
\text { icated "oth }\end{array}$ & $\begin{array}{l}\text { immediate } \\
\text { ation, and } \\
\text { ational cate } \\
\text { training. C } \\
\text { as their fie }\end{array}$ & $\begin{array}{l}\text { identifial } \\
\text { mputer sc } \\
\text { ries. It do } \\
\text { ectively, } 3 \\
\text { of emplo }\end{array}$ & $\begin{array}{l}\text { as occupationa } \\
\text { ce. For exampl } \\
\text { include agricul } \\
\text { people were en } \\
\text { ent, and } 14 \text { res }\end{array}$ & $\begin{array}{l}\text { It does no } \\
\text { computer } \\
\text { ure, indust } \\
\text { ployed in t } \\
\text { onded "no }\end{array}$ & $\begin{array}{l}\text { ot include } \\
\text { r science } \\
\text { trial arts, } \\
\text { these } \\
\text { t }\end{array}$ \\
\hline
\end{tabular}

cupational faculty were more likely than faculty in other fields to have worked in the for-profit sector $(26.2 \%)$, consultancies $(8.6 \%)$, or the federal government $(8.1 \%)$. Over half of the health faculty had held previous jobs in the health industry (51.1\%). Also business faculty were likely to have held their previous position in the for-profit sector (25.2\%); however, this percentage was lower than we expected. In fact, a larger percentage of business faculty had held previous jobs in two-year colleges while only $10 \%$ had worked in four-year colleges and $15.3 \%$ in elementary and secondary schools. 


\section{TABLE 4}

GENDER BY GROUP

\begin{tabular}{|c|c|c|c|c|c|}
\hline & $0-3$ Yrs & 4-10 Yrs & 11-19Yrs & $20+Y r s$ & Totals \\
\hline & \multicolumn{2}{|c|}{ Number/Percentage } & & & \\
\hline Males & $\begin{array}{r}305 \\
32.0\end{array}$ & $\begin{array}{r}274 \\
28.8\end{array}$ & $\begin{array}{r}208 \\
21.8\end{array}$ & $\begin{array}{r}165 \\
17.3\end{array}$ & $\begin{array}{r}952 \\
100 \\
47.3\end{array}$ \\
\hline Females & $\begin{array}{r}443 \\
41.8\end{array}$ & $\begin{array}{r}352 \\
33.2\end{array}$ & $\begin{array}{r}202 \\
19.1\end{array}$ & $\begin{array}{r}62 \\
5.9\end{array}$ & $\begin{array}{r}1,059 \\
100 \\
52.7\end{array}$ \\
\hline
\end{tabular}

\section{Labor Market and Gender}

Slightly more than half of the respondents (52.7\%) who reported a previous main job were women. (Women were actually $49.6 \%$ of our entire sample-1,540 out of 3,104.) (See Table 4.) The gender composition of the community college faculty differs rather dramatically by group. While women were only $5.9 \%$ of the $20+$ group, they comprised $41.8 \%$ of the $0-3$ year group. When we examined previous main job by gender, a few differences jumped out. (See Table 5.) Although we are using cross-sectional data to make this case, it follows the general trend of access into higher education.

The differences in the employment sector of the previous main job by gender are quite stereotypical. Women were more likely than men to have held their immediately previous job in elementary and secondary education (17.5\% compared to $13.8 \%)$ and in the hospital/health care industry (14.2\% compared to $2.9 \%$ ). The latter probably reflects community college programs in nursing, allied health programs, and dental hygiene. On the other hand, men were more likely than women to have been consultants (6.8\% compared to $3.4 \%$ ) in their previous job or to have worked in business $(17.2 \%$ compared to $7.4 \%)$. Presumably many of the faculty with consultancies and or for-profit business are business faculty. When identifying their main responsibility in the previous job, women were more likely than men to have listed teaching (62.2\% compared to $56 \%)$ or clinical $(9.5 \%$ compared to $2.9 \%$ ) as their main responsibility. Men were more likely than women to have held technically oriented previous positions $(15.7 \% \mathrm{com}-$ pared to $5.8 \%$ ). Also stereotypically, men were more likely than women to have held a full-time rather than a part-time previous job ( $86 \%$ compared to $75.7 \%)$. 


\section{TABLE 5}

\section{Employment Sector of Previous Main Job by Gender}

\begin{tabular}{|c|c|c|c|}
\hline \multirow[t]{2}{*}{ Sector } & \multicolumn{2}{|c|}{$\underline{\text { Gender }}$} & \multirow[b]{2}{*}{ Totals } \\
\hline & Male & Female & \\
\hline Four-Year College/University & $\begin{array}{r}153 \\
16.1\end{array}$ & $\begin{array}{r}173 \\
16.3\end{array}$ & $\begin{array}{r}326 \\
16.2\end{array}$ \\
\hline Two-Year Postsecondary & $\begin{array}{r}307 \\
32.2\end{array}$ & $\begin{array}{r}349 \\
32.9\end{array}$ & $\begin{array}{r}656 \\
32.6\end{array}$ \\
\hline Elementary/Secondary Education & $\begin{array}{r}131 \\
13.8\end{array}$ & $\begin{array}{r}185 \\
17.5\end{array}$ & $\begin{array}{r}316 \\
15.7\end{array}$ \\
\hline Consulting & $\begin{array}{r}65 \\
6.8\end{array}$ & $\begin{array}{r}36 \\
3.4\end{array}$ & $\begin{array}{r}101 \\
5.0\end{array}$ \\
\hline Hospital/Health & $\begin{array}{r}28 \\
2.9\end{array}$ & $\begin{array}{r}150 \\
14.2\end{array}$ & $\begin{array}{r}178 \\
8.9\end{array}$ \\
\hline Nonprofit & $\begin{array}{r}17 \\
1.8\end{array}$ & $\begin{array}{r}22 \\
2.1\end{array}$ & $\begin{array}{r}39 \\
1.9\end{array}$ \\
\hline Business & $\begin{array}{r}164 \\
17.2\end{array}$ & $\begin{array}{r}78 \\
7.2\end{array}$ & $\begin{array}{r}242 \\
4.8\end{array}$ \\
\hline Federal Government & $\begin{array}{r}54 \\
5.7\end{array}$ & $\begin{array}{r}43 \\
4.1\end{array}$ & $\begin{array}{r}97 \\
4.8\end{array}$ \\
\hline Other & $\begin{array}{r}33 \\
3.5\end{array}$ & $\begin{array}{r}23 \\
2.2\end{array}$ & $\begin{array}{r}56 \\
2.8\end{array}$ \\
\hline Totals & $\begin{array}{l}952 \\
100\end{array}$ & $\begin{array}{r}1,059 \\
100\end{array}$ & 2,011 \\
\hline
\end{tabular}

\section{Summary, Discussion, and Future Directions}

Because the NSOPF-93 employed a cross-sectional rather than a panel design, we must interpret our analyses involving length of time in current position with some caution. Nonetheless, these comparisons suggest some important insights about differences among community college faculty who have been in their current job varying numbers of years.

\section{Summary of Findings}

1. Overall, community college faculty anticipate retiring from post-secondary education at age 61.5. Men intended to work slightly longer than women. Approximately $45 \%$ of the faculty in their jobs twenty years or more indicated that they were somewhat or very likely to retire in the next three years (or by 1995). Men also anticipated retiring from all employment at slightly older ages than women. 
2. Few community college faculty indicated plans to leave their current job for either a full- or part-time job outside post-secondary education. However, a sizable percentage of faculty intended to seek another job in another post-secondary institution. This intention was especially noticeable in the $0-3$ year $(40 \%)$ and $4-10(35 \%)$ year groups.

3. A third of current (1992) community college faculty had previously been employed by a two-year college as their main job. However, other two-year colleges were not the only source of current faculty. Substantial percentages also came from four-year colleges, elementary/secondary schools, and business.

4. Two-year colleges have more or less maintained their position as the primary source of community college faculty. However, the youngest faculty ( 0 -3 years) were somewhat more likely to have worked earlier at a fouryear college or university than those in longer age groups. As expected, however, we noted a decrease in the percentage of community college faculty who had previously worked in elementary and secondary schools. The percentage of faculty coming from health professions has increased while the percentage from for-profit business has declined or rather returned to the level we found in the 20+ group. These last changes are probably due to program growth and contraction.

5. Two-thirds of the respondents in our sample held the master's as their highest degree. Our analysis suggests that the percentage of community college faculty holding the doctoral degree has not increased substantially. That is, the percentage of faculty holding the doctorate who have been in their current job three years or less was $16.6 \%$. A surprising number of current faculty hold only a bachelor's degree. This aspect of the labor market requires more exploration, but it appears that some portion of those holding a doctorate earned it after taking a job at a community college.

6. Although faculty overall are much more likely to have worked earlier at another two-year college as their main job, faculty in certain academic areas were more likely to have been employed earlier by four-year colleges or elementary and secondary schools. For example, humanities and social science faculty - the foundations of transfer programs in two-year collegeswere more likely to have held a previous main job in a four-year college or university than faculty in other areas. Four-year colleges supplied $17 \%$ of the current science faculty in community colleges. Elementary and secondary schools had previously employed a fifth of the humanities and science faculty in community colleges.

7. Not surprisingly, the vast majority of health faculty had come to their current jobs from positions in hospitals or the health care industry. In fact, this is the only academic area in which an external market is the primary supplier of faculty. Occupational and business faculty are more likely to 
come from the for-profit business sector than they are from other sectors with exception of other two-year colleges.

8 . There are major gender differences among groups based on length of time in current position. Only $6 \%$ of the faculty who had been in their jobs more than twenty years was female compared to $41.8 \%$ of those in their jobs $0-3$ years. Overall, women comprised $49 \%$ of the full-time current community college faculty in the NSOPF-93 data set and 52\% of those who reported a previous main job.

9. Differences between men and women in the sector in which they previously held their main job before being hired at the community college were quite stereotypical. Women were more likely than men to have held their previous main job in elementary and secondary schools. Men were more likely to have held consultancies or jobs in the for-profit business sector.

What do these data tell us about the community college labor market? This analysis leads to six main conclusions about the community college faculty labor market. First, the community college faculty labor market is both stable and dynamic. The mean age of those in their jobs 20 years or more was 55.1 years compared to a mean age of 49.9 for those in the job 1119 years, 46.2 for those in the job 4-10 years, and 43.61 for those in the job 0-3 years. Overall, respondents anticipated retiring from post-secondary education at age 61.5 and from all employment at age 64.5 . Only $25 \%$ of those in their current jobs 20 years or more said they would definitely retire in three years. Another $20 \%$ said they were "somewhat" likely to retire within that time. Women anticipated retiring earlier than men. Consequently, for faculty in the 20+ group, we would anticipate that they would teach for approximately six more years and work for nine more years (from 1992). Over $80 \%$ of the other groups said they were "unlikely" to retire within three years. Although community colleges can anticipate a substantial number of retiring faculty in the next several years, this study suggests that the percentage of faculty who leave will not be so great as to create a crisis.

Those in their current job the shortest length of time (the largest group) also seemed to be the most mobile in the sense that they had stayed in their previous job the shortest period of time and also reported an intention to move in the next three years at a higher rate. Furthermore, most] of those intending to leave their current job would seek another job in post-secondary education. Nearly $40 \%$ of those in their current job three years or less and $35 \%$ of those in their jobs 4-10 years indicated that they might look for another job in post-secondary education.

The data also suggest considerable mobility in the labor market in 1992. Approximately $40 \%$ of the faculty in our data set had been in their job three years or less, indicating that community colleges had obviously been actively hiring in the early 1990s while a large number reported no previous 
position. Some of them were undoubtedly in their first position when they took the survey, suggesting that the percentage of recent hires might even be higher.

Second, discernible patterns of movement in the employment sector between the current and previous positions suggest that the labor market has some structure and therefore does not operate as a classic market. However, based on our analyses, this labor market is apparently not closedmeaning accessible only to those who held previous jobs in a two-year college. Nor does community college teaching have firm entry requirements, such as a master's or doctoral degree. Relatively few faculty in our sample started their job in the same year in which they finished their highest degree. Although one-third of all those who reported a previous main job held that job in another two-year college, two-thirds held a previous job in some other employment sector. Community colleges seek faculty through at least some external or boundary-spanning activities in certain academic areas, namely, health, business, and occupations. That is, they hire from outside community colleges and academe altogether. In particular, 51\% of health faculty come from the health/hospital sector. It is possible that many of the health programs are so new that faculty have not had time to move to a different teaching position. This may change in the future.

Third, based on individuals included in NSOPF-93, a very slight shift has apparently occurred in the external markets that community colleges draw from, especially in the areas of the humanities, social sciences, and sciences. Only $14 \%$ of the current community college faculty in their positions three or fewer years came from the elementary and secondary sector. On the other hand, the four-year college and university sector supplied approximately $18 \%$ of the faculty in their current jobs three or fewer yearsa slight increase. However, no major shift has occurred from the elementary and secondary sector to the four-year college market.

This stability is somewhat surprising, given the excess of qualified faculty and the lack of academic jobs in the four-year sector. It is further surprising because colleges and universities are generally characterized by upward academic drift. That is, when possible they adopt programs, standards, and faculty that characterize higher-status institutions. According to this logic, we would expect community colleges to hire doctorates and/or faculty from four-year colleges, if available, to increase their status. Yet judging by the data presented here, such has not been the case, at least not for full-time faculty. The situation may be quite different among part-time faculty. This situation may change as community colleges continue to become sites for B.A./B.S. degree-completion programs and some fields continue to overproduce Ph.D.'s who want to teach.

Fourth, judging by the educational qualifications of current (1992) faculty, the educational requirement for a full-time faculty job in the commu- 
nity college continues to be the master's degree. A contemporary study might show a different pattern. However, a more likely explanation is that, rather than giving preference to the doctoral degree in hiring, community colleges have found it more efficient to hire candidates with master's degrees and encourage them to earn doctorates. This pattern has the advantage of avoiding any expectation gap between the training and expectations of recent Ph.D. graduates and the work demands of the community college. A Ph.D. candidate without previous experience in the community college has probably internalized the values of the doctoral program while a community college faculty member who earns a doctoral degree can shape or better blend the values of a degree program with the values of the community college. Thus, those who promote the community college as an alternative employment site for their graduate students should encourage them to obtain a master's degree and probably teaching experience. Having secured a position, faculty can then pursue a doctoral degree.

Fifth, one of our more interesting findings was the surprisingly high percentage of two-year college faculty in the humanities, social sciences, and sciences who had previously worked for a four-year college or university. This pattern counters the Caplow and McGee and Burke arguments that one can, but usually does not, move down in institutional status and prestige. One explanation may be that these faculty members were, in a classic labor market sense, searching for the best fit of their skills and the needs of the organization: teaching as opposed to research (Townsend, 1998). Another possibility is that they did not earn tenure in the four-year institution. Or third, though teaching full-time at a four-year college or university, they were non tenure track and/or were on a fixed appointment that expired. On the other hand, the humanities and social sciences are two of the foundational areas of transfer programs in two-year colleges. Thus, hiring former four-year college faculty is a logical and efficient strategy. This hypothesis suggests the importance of further study on the values and preferences in institutional hiring in the arts and sciences.

Sixth, the community college labor market apparently functions neither entirely as an internal labor market nor as a classic open market. Rather it appears to be quite rational and suited to the multiple missions of this sector. Although a substantial proportion of current faculty was hired from other two-year college jobs, a substantial portion was not. Faculty who did not hold previous jobs in two-year colleges tended to come from sectors that, while constituting their own labor market sectors, have direct and close ties to community colleges: four-year colleges/universities and elementary/ secondary schools. The exceptions were occupational and health faculty. To the extent that labor markets reflect (or serve to manage boundaries), it seems that community colleges maintain "dotted line" boundaries with their external markets. Some teaching fields are more likely than others to hire 
faculty from these sectors, but in general community colleges still seek or consider faculty from them. Specifically, community colleges still seem to hire some portion of their faculty from four-year colleges and from elementary/secondary schools and from various professional communities.

Many questions remain about this important labor market sector before sound policy recommendations can be made. The biggest missing piece is the job-matching process itself. How and where do community colleges announce faculty vacancies? What sources do individuals seeking jobs in a community college use? Which skills or attributes are valued most highly in the job search? According to Grubb et al. (1999), it is not teaching. Do these colleges prefer a local or a national faculty? How are faculty salaries derived and do they reflect more than a local market? Part of the answer to these questions derives from what the community college values. For four-year colleges and universities, status and prestige is determined by the faculty's national reputation, which comes from research. If teaching is the primary value in community colleges and national reputation is not important, perhaps one does not have to search nationally to find excellent teachers. The answers to these questions would provide much more detail about the workings of the community college faculty labor market. Indeed, these and other questions must be answered if these colleges will indeed face major vacancies in the coming years. Not only will information about the labor market help community colleges plan for future vacancies, but prospective faculty members also need information so they can make rational decisions about where and how to prepare for teaching careers.

\section{REFERENCES}

Althauser, R. P., \& Kalleberg, A. (1981). Firms, occupations, and the structure of labor markets: A conceptual analysis. In I. Berg (Ed.), Sociological perspectives on labor markets (pp. 119-149). New York: Academic Press.

Bayer, A., \& Braxton, J. (1998). The normative structure of community college teaching. Journal of Higher Education, 69(2), 187-205.

Berubé, M., \& Nelson, C. (1994). Higher education under fire. New York: Routledge.

Brewer, D., \& Gray, M. (1997). Connecting college and community in the new economy? U.S. Department of Education, ED 411033.

Burke, D. (1988). A new academic marketplace. Westport, CT: Greenwood Press.

Caplow, T., \& McGee, R. J. (1958). The academic marketplace. New York; Basic Books.

Carter, D., \& Ottinger, C. (1992). Community college faculty: A profile. ACE Research Briefs, Vol. 3, No. 7.

Chronicle of Higher Education Almanac. (1998, September).

Cohen, A., \& Brawer, F. (1991). The American community college (2nd ed.) San Francisco: Jossey-Bass.

Colgrove, C., \& Shinville, P. (1993, May). Community college faculty dissatisfaction: A comparative analysis. Paper presented at the Annual Forum of the Association for Institutional Research, Chicago, IL. 
Dougherty, K. J. (1994). The contradictory college. Albany: State University of New York Press.

Fairweather, J. S. (1996). Faculty work and the public trust: Restoring the value of teaching and public service in American life. Needham Heights, MA: Allyn and Bacon.

Filan, G., Okun, M., \& Witter, R. (1986). Influence of ascribed and achieved social statuses, values, and rewards on job satisfaction among community college faculty. Community/Junior College Quarterly of Research and Practice, 10(2), 113-122.

Finkelstein, M., Seal, R., \& Schuster, J. (1998). The new academic generation: A profession in transformation. Baltimore, MD: Johns Hopkins University Press.

Finnegan, D. (1993). Segmentation in the academic labor market: Hiring cohorts in comprehensive universities. Journal of Higher Education, 64(6), 621-56.

Fugate, A. (1997). Early career stages of community college faculty. Unpublished doctoral dissertation, University of Kansas, Lawrence.

Grubb, N., \& Associates. (1999). Honored but invisible. New York: Routledge.

Haworth, K. (1999, January 8). More community colleges push to hire Ph.D.'s as professors. Chronicle of Higher Education, 45(8), A12-A13.

Happ, A., \& Yoder, P. (1991, April). Stress, job satisfaction, and the community college faculty. Paper presented at the Annual Meeting of the American Educational Research Association, Chicago, IL.

Huber, M. T. (1998). Community college faculty attitudes and trends, 1997. Stanford, CA: National Center for Post-secondary Improvement, Stanford University.

Kalleberg, A., \& Sorensen, A. (1979). The sociology of labor markets. Annual Review of Sociology, 5, 351-379.

Kerr, C. (1954). Labor markets: Their character and consequences. American Economic Review, 40, 278-291.

National Center for Education Statistics. (1997). Full-time and part-time instructional faculty and staff at institutions of higher education, by type and control, academic rank, age, salary, race/ethnicity, and sex: Fall 1992. Digest of Education Statistics.

Palmer, J. (1994). The scholarly activities of community college faculty: Findings of a national survey. ASHE reader on community colleges ( $2 \mathrm{~d}$ ed., pp. 387400).

Phillippe, K. (1995). National profile of community colleges: Trends \& Statistics, 19951996. ERIC Document Reproduction No. ED381197.

Schuster, J. (1995). Whither the faculty? The changing academic labor market. Educational Record, 76(4), 28-33.

Scott, W. R. (1992). Organizations. (3rd ed.). Englewood Cliffs, NJ: Prentice Hall.

Schultz, T. W. (1965). Administrators for America's junior colleges: Predictions of need, 1965-1980. Washington, DC: American Association of Community and Junior Colleges.

Tillery, D., \& Deegan, W. (1985). Renewing the American community college. San Francisco: Jossey-Bass.

Townsend, B. K. (1998). Women faculty satisfaction with employment in the community college. Community College Journal, 22(7), 655-662. 
Twombly, S. (1988). Administrative labor markets: A test of the existence of internal labor markets in two-year colleges. Journal of Higher Education, 59(6), 668-689.

Wing, D. (1971). The public community college chief administrator during the 1960s. Unpublished doctoral dissertation, University of Colorado. In Dissertation Abstracts International, 32, 1822A. University Microfilms, No. 71-27, 883.

Youn, T., \& Gamson, Z. (1994). Organizational responses to the labor market: A study of faculty searches in comprehensive colleges and universities. Higher Education, 28(2), 189-205. 